\title{
American workplace dispute resolution in the individual rights era
}

\author{
Alexander J.S. Colvin
}

\begin{abstract}
This article presents a theoretical conceptualization of the rise of alternative dispute resolution and its impact on American employment relations in the individual rights era. The idea of an industrial relations system advanced by Dunlop is no longer a plausible general approach for understanding American employment relations given the decline of organized labor. This article examines the question of whether a new individual employment rights-based system of employment relations has replaced it. The old New Deal industrial relations system was based on three pillars: labor contracts that provided a web of rules governing the workplace; economic strikes, actual or threatened, which provided the bargaining power for unions to negotiate these contracts; and labor arbitration, which provided the workplace dispute resolution mechanism for enforcing these contracts. The institutions of the new individual employment rights era can be seen as based on three parallel elements: individual employment rights provide the new web of rules; litigation, actual or threatened, provides the new source of bargaining power for employees; and alternative dispute resolution procedures provide the new workplace-based mechanism for enforcing individual rights. However, each of these elements contains substantial limitations, which makes the institutional structures of the new individual employment rights era something different from a new Dunlopian integrated system.
\end{abstract}

\section{Introduction}

The rise of alternative dispute resolution (ADR) procedures represents a major, yet under theorized development in employment relations. The tendency has been to treat ADR as a set of techniques that can be examined in isolation. From a technique-based perspective, arbitration and mediation, or other approaches such as ombudspersons and peer review, can be evaluated based on how well they achieve some generic goal of effective conflict resolution (Budd and Colvin 2008). However, the ways in which conflicts are resolved in the workplace have implications that go beyond the question of how to handle an individual dispute and instead implicate the broader structure of employment relations. This article examines conflict resolution in the American workplace and analyzes the impact of the rise of ADR with a view to understand the role of these procedures in a transformed system of employment relations. In particular, it is argued that ADR procedures need to be understood as a key pillar of a new individual rights era of employment relations that is replacing the older collective bargaining-based industrial relations system.

In the 1950s heyday of the American labor movement, it was plausible to think of industrial relations in the United States as a coherent industrial relations system that governed relations between labor and management (Dunlop 1958). The conflicts that arise naturally in the workplace would be 
resolved by a combination of collective bargaining for resolving interest disputes, with government intervention confined to offering mediation services where needed, and grievance procedures culminating in labor arbitration for rights disputes, administered privately at the direction of unions and employers. However, with the decline in levels of union representation over the subsequent decades it has become clear that the vision of an industrial relations system based on the New Deal labor laws, and widespread union representation and collective bargaining is no longer a plausible general characterization of American employment relations. The question then becomes how to characterize what has replaced or will replace it.

Many industrial relations scholars have looked for or advocated the development of a new industrial relations system characterized by a revitalized labor movement and reformed labor laws to remedy deficiencies in the existing labor laws (Friedman, Hurd, Oswald and Seeber 1994). Although it would not be wise to rule out the possibility of such a transformation, given the abrupt changes that have occurred in the past, as of yet there is a lack of evidence of such a change in union representation levels and prospects for labor law reform remain uncertain. Some economists and management scholars have viewed this decline of the American labor movement and shrinkage of collective bargaining representation as a positive development (for a general discussion of these different perspectives see Budd 2004). In this view, the current American employment relations system is the one exemplifying the advantages of a free market for labor, unconstrained by market distorting unions or excessive government regulation, and resulting in high levels of economic and labor market performance. From a human resource management perspective, this American employment relations system can be seen as allowing employers the freedom to develop optimal human resource strategies for their businesses, aligning the interests of employers and employees.

Set against these perspectives, other scholars have argued that a new employment relations system is already emerging, which, while not being characterized by widespread union representation, is more respectful of individual employee interests than the image of an unconstrained labor market would suggest. This perspective emphasizes the significance of the expansion over the recent decades of laws protecting individual rights in the workplace. For example, researchers in the 'new institutionalist' literature in sociology have argued that organizations in the United States responded to the normative environment created by the enactment of civil rights laws prohibiting discrimination in employment by adopting organizational policies and procedures that met social and cultural norms of due process (Edelman 1990; Sutton, Dobbin, Meyer and Scott 1994; Sutton and Dobbin 1996; Edelman, Uggen and Erlanger 1999; Godard 2002, p. 253). Even without strong direct regulation of the workplace, these 
researchers argue that the passage of laws protecting individual employment rights have a broad impact as organizations seek to engage in socially and culturally desirable behaviors that comply with norms emanating from the legal system. In addition to the passage of employment discrimination laws, in the 1970s and 1980s state courts began to recognize new common law actions by employees for wrongful dismissal. Among others, Edwards (1993), in the book Rights at Work, argued that these new common law rights could provide the basis for a new employment relations system protecting employee rights in the workplace in the absence of unions. More recently, Piore and Safford (2006) argued that the expansion of individual employment rights, combined with the growth of employee interest groups, organized individual characteristics such as race, gender, and sexual orientation, and the development of new workplace dispute resolution procedures for resolving individual rights claims, already constitutes a nascent 'individual employment rights system' governing employment relations. If accurate, these perspectives suggest a more hopeful vision for protection of employee rights in the American workplace, albeit one that is very different from traditional industrial relations visions of desirable systems for governing employment relations.

This article explores the question of whether it is accurate to view a new individual employment rights system governing employment relations as emerging out of the conjunction of: expanded individual employment rights laws; employee mobilization of these new legal rights to exert pressure on employers; and the development of new ADR mechanisms to resolve conflict in the workplace. The old collective bargaining-based industrial relations system was based on three inter-related pillars. Employment relations in the workplace were governed by detailed labor contracts that established a 'web of rules' (Dunlop 1958) regulating work and employment decision-making in the workplace. These rules governing the workplace were negotiated based on the bargaining power of the parties, which derived from the ability of the labor to launch and the management to resist strikes. In this way, actual or potential strike action provided the key determinant of the outcome of interest disputes in the workplace. Finally, enforcement of labor contracts and resolution of rights disputes in the workplace occurred through jointly administered grievance procedures that culminated in binding, neutral labor arbitration.

The new individual rights-based employment relations system contains elements that parallel these three pillars. First, individual employment rights established by statutes and the courts are arguably establishing a new web of rules governing employment relations, akin to the rights established in labor contracts. Second, litigation provides employees with a new source of bargaining power in the workplace, akin to the strike power used to resolve interest disputes in traditional industrial relations. 
Finally, the expansion of employment arbitration and other ADR mechanisms such as peer review and mediation have established a new system of workplace dispute resolution, akin to the labor arbitration and grievance procedures for resolving rights disputes in the old collective bargaining-based industrial relations system. However, in each of these areas there are potential limitations to these 'pillars' of the new individual rights employment relations system. Subsequent sections examine the evidence on the extent and role of these three new pillars and evaluate the degree to which they are providing the foundation for a new individual rights-based employment relations system.

\section{Web of rules: individual rights laws}

\section{Rise of individual employment rights laws}

Labor contracts negotiated jointly by unions and management provided the governance rules pillar of the collective bargaining-based industrial relations system. A central component of the concept of the rise of an individual employment rights system governing employment relations is that there has been an expansion of laws providing individual employees with rights in the workplace. Whereas American labor law continues to be based on the aging foundation of the National Labor Relations Act passed in 1937, with the last major amendments coming in the 1947 Taft-Hartley Act and 1959 Landrum- Griffin Act, individual employment law in the United States has expanded substantially in recent decades, beginning with the passage of the landmark Civil Rights Act of 1964. The chronology of the employment laws passed since that time is a story of the expanding recognition of employee rights in the workplace. Title VII of the Civil Rights Act of 1964 began by prohibiting discrimination in employment on the basis of race, color, sex, religion, or national origin. This was followed by the Age Discrimination in Employment Act (ADEA) in 1967, prohibiting discrimination against older workers over the age of 40 .

The Pregnancy Discrimination Act of 1978 affirmed that discrimination on the basis of sex included discrimination on the basis of pregnancy. In 1990, Congress passed the Americans with Disabilities Act, prohibiting discrimination based on disabilities and establishing positive duties on employers to accommodate workers with disabilities. This was followed by the Civil Rights Act of 1991, which strengthened the protections of Title VII by expanding available remedies to include compensatory and punitive damages that could now be awarded by juries, as well as reversing a series of Supreme Court holdings that hindered the ability of employees to make discrimination claims. Finally, at the federal level, in 1993 Congress passed the Family and Medical Leave Act (FMLA), providing 
workers with an entitlement of up to 12 weeks of unpaid leave to deal with medical problems, care for a sick family member, or for birth or adoption of a child.

These federal laws were supplemented by parallel state-level individual employment rights statutes that in some areas extended protections beyond those offered in the federal statutes. For example, some states (as of writing 21 out of 50 ) included sexual orientation as a prohibited ground of discrimination, which is not covered under the federal statutes. In addition, both New York and California passed so-called 'lifestyle' protection statutes barring discrimination in employment based on non-work-related lifestyles or activities. More common were the 'smokers' rights' statutes passed by a number of states prohibiting discrimination against tobacco smokers in the workplace (though one might speculate that this may have owed more to the strength of the tobacco industry lobby than to general employment rights concerns). Notably, California recently supplemented the federal FMLA rights by providing an entitlement to six weeks paid leave for family or medical needs.

Looking at the swath of individual employment rights that have been enacted in recent decades, it is not unreasonable to think that the American workplace is becoming an increasingly regulated place, with employees having a broad set of rights being legally recognized. While this is arguably an accurate characterization of the law relating to discrimination, it is also important to recognize the limitations of this approach to individual employee rights. One important limitation is that these statutes were limited to recognition of rights against decisions being made on specific grounds, rather than providing any general requirement of fairness or due process in employment relations. For example, the ADEA prohibits discrimination against older workers over the age of 40 and so provides no protection against decisions being based on the youth of the worker or on age if that worker is under 40 . Similarly, unless the employee works in one of the 13 states that have chosen to include sexual orientation in their state statutes, employees have no legal cause of action to complain about being fired or otherwise being discriminated against on the basis of their sexual orientation. This general limitation of the individual employment rights laws approach is illustrated by the issue of harassment of employees in the workplace. By now it is well known that Title VII prohibits sexual harassment in the workplace. This has had a major impact in the workplace with many organizations adopting policies designed to prevent such harassment from occurring. Much as sexual harassment is prohibited by Title VII, harassment based on any of the other grounds covered by the employment discrimination statutes is also prohibited, so harassment based on race, religion, age, or disability status is similarly prohibited. However, harassment motivated by reasons other than these specific grounds is not covered by individual rights law. So an employee subject to bullying motivated by generic interpersonal resentment or conflict has no legal 
entitlement to a remedy, even though he or she may clearly be a victim of harassment. In this way, employment discrimination law in the United States is notable for both the strength of its protections accorded to employees in specific areas and for the lack of protections outside these areas.

\section{Stickiness of employment-at-will}

What of the general law governing employment relations? In addition to the passage of individual rights laws prohibiting various types of discrimination in employment, there has been a growth in recognition of 'common law' employment rights by state courts since the 1970s and 1980s. Some have viewed these new judicially recognized common law rights as helpful to fill in the areas of employee rights left unprotected by the employment discrimination statutes to create a broad patchwork quilt of individual employee rights against unfair treatment in the workplace. For example, one introductory textbook on American employment law described the situation in the workplace as follows:

Visualize a whole luscious, delectable pie of your favorite type. That pie represents the employer's rights in the workplace. At first, virtually the whole pie belonged to the employer. The employer could do practically anything the employer wished to do regarding the right to hire, fire, pay, or legislate employee activities in the workplace. Then congress began passing laws that limited in some way the employer's prerogatives.... Then along comes the weakening of the employment-at-will concept, and much of the pie the employer though was left is taken away. The amount of pie left to the employer is enough to be a filling portion, but much less than the employer initially though he or she would have for disposal. (Bennett-Alexander and Hartman 2004, p. 11)

Although it is undeniably the case that individual employment rights laws have expanded in recent decades, this type of statement creates a very misleading picture of the actual extent of employment law protections. To develop this point further, it is necessary to look at the new state common law employment rights in more detail.

In the United States, the default rule governing employment is that of employment-at will. Under this rule, employers are allowed to fire employees for any reason, good or bad, without notice or any possibility of the employee successfully challenging the decision in court. This continues to be the basic rule governing employment in all American states, with the lone exception of Montana. A representative modern statement of the rule by the Pennsylvania Supreme Court states that, 'Absent a statutory or contractual provision to the contrary, the law has taken for granted the power of either party to terminate an employment relationship for any or no reason' (Geary v. US Steel Corporation, 456 Pa. 171 [1974]). Statutory exceptions to this rule have been largely confined to the area of employment 
discrimination law. Contractual exceptions are largely limited to employees such as executives and sports or entertainment stars with exceptionally high individual bargaining power or unionized employees. For the majority of American workers in typical discharge situations, the employment-at-will ensures that the employee will have no legal remedy available for preemptory dismissal without just cause.

As noted, in recent years attention has been given to a set of exceptions that state courts have created over the past two decades to the general employment-at-will rule and suggestions have been raised whether this might represent a more general shift in employment law in the United States away from employment-at-will (e.g. Edwards 1993). Various state courts have recognized one or more of the four main types of exceptions to the employment-at-will rule: discharges in violation of public policy; implied contracts; covenants of good faith and fair dealing; and employee handbooks. When one examines the cases that have considered the scope of these exceptions, however, it becomes clear that the exceptions are much narrower and of less impact than has sometimes been claimed. To take a relatively representative example, Pennsylvania's state courts occupy a middle position among the state courts in that they have recognized all of these exceptions apart from the covenant of good faith and fair dealing, which is the least commonly recognized of the exceptions (Block and Roberts 2000; Block, Roberts and Clarke 2003).

The public policy exception has been accepted by Pennsylvania courts, for example in a case where an employee was fired for having pursued a workers' compensation claim allowed under state law (Shick v. Shirey, 552 Pa. 590 [1998]). However, where an employee was similarly fired for making complaints about the employer's violation of federal Occupational Safety and Health Act standards regarding dangerous chemicals, the Supreme Court of Pennsylvania held that this did not fall under the public policy exception because it involved a federal rather than a state law and that only state laws could form the basis of public policy for purposes of the exception (McLaughlin v. Gastrointestinal Specialists, 561 Pa. 307 [2000]). Similarly, although Pennsylvania courts recognize that handbook promises of just cause before dismissal can create a contract modifying employment-at-will, in practice they have construed this exception very narrowly. For example, in a case where the company's employee handbook stated 'You may only be discharged for just cause...', the court held that this language did not ' . . . evidence an intent to create an implied contract whereby [the employee] could be discharged for objective just cause only.' (Luteran v. Loral Fairchild Corp., 455 Pa. Supp. 364 [1997]). In practice, the only situation in which a handbook could create an exception to employment-at-will under 
this approach is where the employer made direct and specific efforts to ensure that it was contracting out of employment-at-will.

Although there is some variation across states in the interpretation of the exceptions to employment-at-will, even in California, which has generally been viewed as having the strongest exceptions to the traditional at-will rule (Sutton et al. 1994), in recent years there has been a shift to more pro-employer decisions. For example, in 1998 the California Supreme Court held that an employer did not engage in an unjust dismissal even when there was an implied contract modifying the at-will rule so long as its subjective intent was based on something that would have constituted just cause, even if the objective facts turned out not to provide just cause for the dismissal (Cotran v. Rollins Hudig Hall, 17 Cal.4th 93 [1998]). So, for example, an employer who honestly thought that an employee was engaged in workplace theft would not be liable for firing that employee, even if the accusation of theft turned out to be untrue.

There is a stark contrast in American law between the areas of employment discrimination and wrongful dismissal. If one just focuses on laws covering employment discrimination, the United States appears to have a relatively extensive set of individual employment law rights. However, broadening the picture to include the general issue of wrongful dismissal illustrates the limited extent of the employment law protections in the United States. Compared to the paradigm of a deregulated labor market with employment law limited to the enforcement of individually negotiated contracts and a default rule of employment-at-will, the developing system of individual employment rights may appear as a glass half-full, gradually being filled as new rights are recognized and adopted. By contrast, if we compare the new system of individual employment rights laws with the old industrial relations system based on detailed labor contracts governing the full range of workplace employment decision-making, then the new system looks to be more of a glass half-empty. Some important new rights have been established, but they are much more limited than what they replaced. This image of a half-full, halfempty glass will be mirrored when we consider the extent and impact of litigation-based conflict in the new system and again when we further consider the new ADR mechanisms that have been developed.

\section{Sources of power: the litigation threat}

The strike weapon provided the bargaining power pillar of the collective bargaining-based industrial relations system. Even though strikes were, and are even more so now, relatively infrequent occurrences, the threat of strikes provided the underpinning of labor bargaining power at the negotiating table and the key to achieving union goals for labor contracts (Katz, Kochan and Colvin 
2008). In the new individual rights employment relations system, the threat of lawsuits provides a parallel role in exerting pressure on the employers to ensure fair treatment of employees in the workplace. But how common are lawsuits and what are their results? These questions are critical for understanding the impact of employment law in the American workplace as they directly affect the strength of the litigation threat and the resulting 'bargaining power' it creates for the employees. Popular images of runaway juries and 'mega-verdicts' can be contrasted with a situation where employment-at-will remains the applicable legal rule for most legal claims and significant barriers to access to the litigation system exist for employees who do have potential legal claims. This section examines three issues related to the impact of litigation. First, what is the extent of legal claims, given the limitations of substantive employment law in the United States? Second, what are the prospects for employee success in litigation? And finally, what are the outcomes in damages where employees are successful in lawsuits?

Among the more commonly cited statistics indicating the explosion of employment litigation are the growth in the numbers of complaints filed with the Equal Employment Opportunity Commission (EEOC) and the numbers of employment discrimination lawsuits filed. Over the course of the 1990s, the number of employment discrimination lawsuits filed in the federal courts increased from 6936 in 1990 to 22,359 in 2000 . In the 2000s, the number of employment discrimination charges filed with the EEOC grew from 79,896 in 2000 to 93,277 in 2009 . These numbers certainly support the image of an explosion of employment litigation. At the same time, it should be recognized that relative to the overall workforce size, the number of employment discrimination complaints is small. To take one state's experience as an example, over the three-year period, 1997-2000, the average annual number of employment discrimination complaints filed with the Pennsylvania Human Relations Commission was 6058 (Pennsylvania Human Relations Commission (PHRC) Annual Reports 1997-1998, 1998-1999, and 1999-2000), which may sound large, but only represents an annual rate of 50.5 complaints per 100,000 residents of the state (Colvin 2006). This rate suggests that a discrimination complaint or lawsuit is an unusual event for an individual employee. On the other hand, if there is around one complaint per year for every 2000 people, then it would not be unusual for a larger employer with a workforce of even over a thousand to experience a complaint.

How do employees who file lawsuits fare in the courts? Looking just at verdicts in jury trials, employees have a reasonable win rate of $38 \%$, though this drops to $21 \%$ for judge-only trials (Clermont and Schwab 2003). However, looking only at trial outcomes misses the high degree of success that employers have had in getting employment discrimination lawsuits dismissed in preliminary proceedings 
before trial. Taking this into account, the overall employee win rate drops to only $13 \%$. Clermont and Schwab (2003) describe a litigation pyramid in which many cases are dismissed before trial and even The International Journal of Human Resource Management 465 Downloaded by when employees are successful at trial a relatively high proportion of judgments are successfully overturned on appeal by employers.

For employees who are successful, however, there is the potential for receiving substantial damage awards. One of the most commonly cited statistics on damage awards in employment litigation is a RAND study showing an average award of $\$ 640,000$ in California state courts between 1980 and 1986 (Dertouzos, Holland and Ebner 1988). It should be noted, however, that California has traditionally been known as the most employee-friendly state court system and these results are from the period of initial expansion of common law exceptions to employment-at-will, which may not be representative of other states and other time periods. For example, a more recent study of state court employment case verdicts in 1996 from 45 counties nationwide found an average award of $\$ 207,000$ (Eisenberg and Hill 2003). Turning to federal cases, a recent study examining employment discrimination cases in the federal courts between 1994 and 2000 in which damages were awarded found a median award of $\$ 110,000$ and a mean award of US\$301,000 (Eisenberg and Schlanger 2003). The large difference between the mean and median award amounts reflects the strongly skewed distribution of awards, with a number of cases where over a million dollars were awarded heavily influencing the mean.

Taken together, the empirical evidence reflects the contradictory nature of employment litigation in the United States. Although there have been large increases in the volume of discrimination complaints and lawsuits filed, these remain infrequent events for individual employees though much less so for employers, particularly those with larger workforces. The chances of an employee winning a verdict at trial are reasonably high, but the chances of actually getting to trial without the lawsuit being dismissed at preliminary stages are much lower. Finally, for the few employees who do get awarded verdicts at trial, the potential damages are quite substantial. As a result, it may be correct to say that the accessibility of the employment litigation system for employees is low and that there are substantial risks and threats from lawsuits for employers. This is inherent in the high-risk, high-return nature of the employment litigation system. In this respect, the role of employment litigation in the individual rights system has parallels to that of strikes in the collective bargaining-based industrial relations system. Both strikes and litigation are infrequent, risky, and destructive events that are generally to the advantage of neither the employer nor the employer. However, the risky and destructive nature of these events is 
what creates the power of strikes and litigation to influence decision-making at the bargaining table or in human resource policies and practices, respectively.

\section{ADR in the workplace}

Do Gilmer and Circuit City have the makings of a new arbitration trilogy?

Labor arbitration provided the workplace dispute resolution pillar of the collective bargainingbased industrial relations system. Widespread adoption of labor arbitration to resolve workplace disputes was initially pushed by the War Labor Board during World War II to discourage strikes from disrupting the wartime economy. While the right to strike was restored following the end of wartime regulations on the economy, labor arbitration remained in widespread use for resolving disputes that arose during the term of labor contracts, which generally included no-strike clauses. Although already used in most labor contracts, the Supreme Court provided a major boost to the system of labor arbitration in 1960 with the issuance of the landmark Steelworkers Trilogy of cases, in which it established strong ground-rules for the courts' enforcement of and deferral to labor arbitration. The system of grievance procedures culminating in neutral, binding labor arbitration has proved highly successful for both enforcing labor contracts and ensuring fairness and due process in the workplace. As a result, whereas many features of unionized industrial relations have undergone major transformations in recent decades, the system of labor arbitration is noteworthy for its lack of change, with almost all unionized workplaces featuring very similar grievance procedures culminating in binding arbitration (Eaton and Keefe 1999).

Historically, nonunion workplaces were more noteworthy for their lack of effective workplace dispute resolution procedures. Although a few companies adopted innovative and effective grievance procedures for nonunion employees, the majority of them were ineffective and infrequently used by the workers (Slichter, Healy and Livernash 1960). This situation began to change during the 1970s and 1980s when an increasing number of companies adopted new types of nonunion grievance procedures for varying motivations, including union substitution, litigation avoidance, and productivity enhancement (Ewing 1989; Colvin 2003a). By the late 1980s, estimates suggest that almost half of the American companies had some type of formal grievance procedure for nonunion employees (Lewin 1990; Feuille and Delaney 1992). The structure of these nonunion grievance procedures varied widely and many would fall far short of the due process standards found in labor arbitration or in the court system (Ewing 1989; Feuille and Chachere 1995). However, although usage levels of these procedures were substantially lower than those of grievance procedures in unionized workplaces, evidence suggested 
that grievance rates for at least some nonunion procedures were not negligible and employees were winning up to a third or a half of these grievances (Lewin 1987, 1990).

The development of ADR procedures covering nonunion employees received a major impetus in 1991 with the Supreme Court's decision in the case of Gilmer v. Interstate/Johnson Lane (500 U.S. 20 [1991]). During the 1980s the Supreme Court had decided a series of cases reversing its historical opposition to the use of arbitration to resolve claims based on statutory rights. While these decisions dealt with other areas of the law, such as Racketeer Influenced and Corrupt Organizations (RICO), Antitrust, and the Securities Acts, in Gilmer the Court for the first time extended this line of reasoning to hold that an arbitration agreement could apply to the resolution of a dispute based on a statutory employment right. The major practical implication of the Gilmer decision was that employers could require their nonunion employees to sign, as a condition of employment, agreements to arbitrate any claim they might bring against the employer based on a right contained in an employment statute, such as Title VII of the Civil Rights Act, Age Discrimination in Employment Act, Americans with Disabilities Act, or the Fair Labor Standards Act. Since under the Federal Arbitration Act and relevant court decisions the ability to appeal arbitration decisions to the courts is highly circumscribed, the effect was to preclude employees who had signed these agreements from taking claims against their employer to court and instead requiring their resolution through arbitration. In contrast to the labor arbitration procedures jointly negotiated between unions and management, these new employment arbitration procedures were based on adhesive contracts promulgated by management, often described as 'mandatory arbitration', giving rise to concerns from critics that they would be systematically biased in favor of management (Stone 1996; Schwartz 2008). The legal trend in favor of employment arbitration was reinforced by the US Supreme Court's 2001 decision in Circuit City v. Adams (532 U.S. 105 [2001]), which upheld the enforcement of an employer-promulgated mandatory arbitration agreement in an employment contract that covered a statutory employment discrimination claim.

From the management perspective, employment arbitration offered the opportunity to escape from the costs, uncertainties, and dangers of runaway jury awards of the litigation system. Viewed positively, the rise of employment arbitration could be seen as providing employees with a cheaper, faster alternative to the overly elaborate litigation system (Sherwyn, Estreicher and Heise 2005). As Estreicher (2001) has described it, employment arbitration could be a 'Saturn' alternative to the overly expensive 'Cadillac' justice system of the courts and the 'Rickshaw' justice of typical nonunion workplaces that have not adopted the ADR procedures. In this vision, Gilmer and Circuit City could be the foundation of a new arbitration trilogy establishing a more effective workplace dispute resolution 
system for nonunion employees (Sherwyn et al. 2005; Piore and Safford 2006). On the other hand, critics were worried that employment arbitration will be inherently biased due to its origin in employerpromulgated mandatory arbitration agreements and employer domination of the process of arbitration (Stone 1996; Bingham 1998; Schwartz 2008).

\section{How extensive are nonunion ADR procedures?}

What does the empirical evidence tell us about the state of dispute resolution in the American nonunion workplace and employment arbitration in particular? Although historically US dispute resolution research has focused on unionized workplaces, there has recently been a growth in research on the incidence, structure, usage, and impact of nonunion workplace dispute resolution procedures.

One of the first important research questions in the nonunion setting is to identify the origins, extent, and structure of dispute resolution procedures. Whereas union grievance procedures are almost universal in incidence and highly uniform in structure, nonunion procedures are characterized by a high degree of diversity in incidence and form. Some of the initial research efforts examining the nonunion grievance procedures in the 1980s focused on trying to categorize the different types of procedures in use through sets of case studies of procedures in different companies (McCabe 1988; Westin and Felieu 1988; Ewing 1989). This research identified a range of different types of nonunion procedures in operation, including open-door policies, investigators, appeal to higher management, management appeal boards, peer-review panels, grievance arbitration, and ombudspersons (Feuille and Delaney 1992). Surveys by Berenbeim (1980) and Lewin (1990) suggested that half of the companies or more had some type of formal nonunion grievance procedure in place. In one of the first studies to systematically examine variation in the structure of nonunion grievance procedures, Feuille and Chachere (1995) found a wide variation in procedures across three key due process dimensions of the coverage of the procedure, availability of representation for employees, and use of a neutral decision-maker. One of the most worrying aspects of their findings, based on the data collected in 1991 from respondents who were graduates of a professional IRHR Masters program (likely skewing the results to reflect companies with more sophisticated human resource management policies), is that only 11 out of 111 companies with formal nonunion grievance procedures utilized non-managers as decision-makers (seven used peer review and four used arbitration). A subsequent study by Colvin (2003a) of dispute resolution procedures among establishments in the telecommunications industry based on a 1998 survey found higher incidences of procedures using non-managerial decision-makers, with $16.3 \%$ using arbitration and $15.9 \%$ using peer review. Although these results may, in part, be different due to industry specific 
factors, such as the adoption of peer-review procedures as a union substitution device given the still relatively high unionization rates in the telecommunications industry, they also reflect the growth of employment arbitration during the 1990s.

There is no periodic national survey of organizations that would provide precise information on the growth of employment arbitration, however a series of different surveys conducted since the Gilmer decision in 1991 give some rough measure of the scope of expansion. Feuille and Chachere's survey data collected in 1991 provide an approximate upper limit on the incidence of employment arbitration at that point in time of $2.1 \%$ of their overall sample of 195 companies, including those without formal procedures (1995). A 1995 survey by General Accounting Office (GAO) indicated that around 7.6\% of firms subject to EEOC reporting requirements had adopted employment arbitration procedures by that point in time, on the basis of a sample of 1448 companies (GAO 1995). The 1998 telecommunications industry survey results of Colvin (2003a) found a $16.3 \%$ incidence of employment arbitration based on a sample of 213 establishments. However, a subsequent survey, in 2003, of establishments in the same industry with a larger sample size ( $\mathrm{n} 1 / 4291$ ) found a similar, but slightly lower, incidence of $14.1 \%$ for employment arbitration (Colvin 2004a). More recently a survey of business units by Lewin (2008) found that of those that had adopted nonunion dispute resolution procedures, most included employment arbitration in their procedures. Overall, what these surveys suggest is a relatively rapid growth of employment arbitration procedures during the 1990s and 2000s in response to the impetus of the Gilmer and Circuit City decisions. Although still present in a minority of workplaces, it is striking that within a decade and a half of its initiation, employment arbitration has grown to the point where it very likely covers over twice as many employees as union representation, which currently stands at only $12.3 \%$ of the American workforce.

One interesting question is why, given the advantages that both advocates and critics argue employment arbitration holds for employers, not all of them have adopted employment arbitration? A possible explanation is that companies are reluctant to adopt new types of procedures with their attendant uncertainties and potential impact on workplace decision-making unless there is a strong impetus, for example from external pressures on the company. In an example of this, in a case study of the ADR procedures at TRW, a major US auto parts and aerospace company, Colvin (2004b) found that the impetus for adoption of employment arbitration came from an upsurge of downsizing related employment litigation in the early 1990s. Support for this explanation is provided by survey data indicating that organizations exposed to greater litigation threats were more likely to adopt employment arbitration, whereas by contrast organizations with greater concerns about union 
organizing threats were more likely to adopt peer-review procedures (Colvin 2003a). This suggests that employment arbitration needs to be understood as motivated in large measure as a defensive shield to protect companies from the threat of litigation. However, this does not mean that its consequences for employees as a result will be inherently negative. To address this issue, it is necessary to turn to the evidence on the usage and impact of procedures.

\section{Usage and impact of ADR procedures}

Perhaps, the most basic question relating to the operation of employment arbitration is how the outcomes of arbitration cases compare with those resolved through the standard litigation process. One approach to answering this question is to simply compare the results of past arbitration and litigation cases. Early studies by Delikat and Kleiner (2003) and Eisenberg and Hill (2003) suggested that outcomes in arbitration and litigation were relatively similar. However, these studies compared litigation outcomes with arbitration in the contexts of the securities industry (Delikat and Kleiner 2003) and under individually negotiated arbitration agreements (Eisenberg and Hill 2003), which tend to involve relatively highly paid professionals and executives likely to have more personal resources, better representation, and greater prospects of success in dispute resolution. More recent research has examined larger datasets of employment arbitration cases administered by the American Arbitration Association or AAA (the largest private organization providing arbitration services in the United States), which included only cases brought under the type of mandatory employer-promulgated arbitration procedure considered in the Circuit City case (Colvin 2008). This research found an employee win rate in mandatory arbitration hearings of only $21.4 \%$ (Colvin 2011), which is substantially lower than the employee win rates found in studies of litigation trials, which range from $36.4 \%$ in the federal courts (Eisenberg and Hill 2003) to $59 \%$ in state courts (Oppenheimer 2003). Similarly, the median damage award received by employees was $\$ 36,500$ in employment arbitration (Colvin 2011) compared to median damage awards for employees as high as $\$ 150,500$ in federal courts (Eisenberg and Hill 2003) and \$296,991 in California state courts (Oppenheimer 2003). These results indicate that outcomes from mandatory arbitration cases are much less favorable to employees than those from employment litigation in the US courts.

One key potential advantage of arbitration over litigation is that it provides a simpler dispute resolution procedure and faster access to justice than litigation. In this area, Colvin (2011) found that the mean time to receive a hearing in mandatory arbitration was 361.5 days. This compares favorably to average times to trial in litigation of 709 days in federal courts or 818 days in state courts (Eisenberg and Hill 2003). Greater speed to trial has a clear advantage in employment disputes as it reduces the period 
of ongoing disruption to individuals' careers and to organizational functioning. It is also likely to reduce the costs of retaining counsel and other expenses involved in the litigation process. One limitation of the studies comparing the outcomes of past arbitration and litigation cases is that they do not control for selection effects in the types of cases that come before arbitration and litigation forums. It is likely that the decisions to proceed to arbitration or litigation will be influenced by calculations of the likelihood of success in the respective forums and the costs attendant to proceeding with the case. As a result, the cases that are subject to decision may not be comparable between arbitration and litigation. Partly to address this problem, Wheeler, Klaas and Mahony (2004) conducted a policy capturing study in which they presented a series of hypothetical cases to both employment arbitrators and people who had served on juries, as well as other types of decision-makers including human resource managers, peerreview panel members, and labor arbitrators. The key finding from this study is that employment arbitrators were much less likely than other decision-makers, including jurors, presented with the same set of facts to find in favor of employee plaintiffs and overturn terminations (Wheeler et al. 2004). In a similar experimental study, Bingham and Mesch (2000) found that employment arbitrators were less likely to order reinstatement than labor arbitrators when presented with similar facts, however this effect became non-significant when additional controls were included in the analysis.

A more specific concern with employment arbitration is that there may be a repeat player bias in which employers are at an advantage in arbitration as repeat players, compared to the one-shot player employees. Arbitrators could tend to favor repeat-player employers in hopes of securing future business. In a series of studies, Bingham $(1995,1996,1997,1998)$ found evidence supporting the existence of a repeat-player bias in favor of employers in AAA arbitration decisions. By contrast, Hill (2003) did not find evidence for a repeat player effect in a study of AAA decisions from 1999 to 2000. Hill and others also criticized Bingham's studies for only showing the advantages of being a repeat player, which are likely to accrue to any large employer involved in multiple cases, such as greater resources, ability to retain superior legal representation, and greater experience with the dispute resolution forum. By contrast, more recent research by Colvin (2011) using a larger data-set of 1210 mandatory employment arbitration cases administered by the AAA found that employees were significantly less likely to win and received significantly lower damages in cases where the employer and the same arbitrator were involved in multiple cases together. This finding suggests a more problematic repeat employer-arbitrator pairing bias in which employers are getting more favorable results when the same arbitrator has decided multiple cases involving the same employer. 
Although most of the attention in empirical research on employment arbitration has focused on the outcomes of arbitration hearings, it is important to consider the broader impact of employment arbitration on the workplace. By comparison, labor arbitration is only the final stage in typical union grievance procedures, with the threat of binding arbitration serving to encourage and guiding resolution by the parties in earlier stages of the procedures. Employment arbitration could conceivably fill a similar role as the final stage in multistep nonunion workplace ADR procedures (Colvin 2001). In a comparison of union and nonunion grievance procedures with different types of final decision-makers, Colvin (2003b) found evidence that nonunion procedures incorporating arbitration as a final step had, compared to other nonunion procedures, significantly higher grievance rates (3.2 versus 1.3 grievances, respectively, per 100 employees annually) and a higher proportion of all dismissal and disciplinary decisions overturned ( $11.1 \%$ versus $2.7 \%$, respectively). Interestingly, the use of peer review in nonunion grievance procedures had similar effects on grievance rates and rates of overturning dismissal and discipline, suggesting that the presence of a non-managerial decision-maker is a critical factor in the usage of nonunion procedures. By contrast, in unionized workplaces both grievance rates (5.3 per 100 employees) and the proportion of dismissal and discipline overturned (17.3\%) were substantially higher than for nonunion procedures even with employment arbitration or peer review. This suggests a mixed picture in which employment arbitration or peer review is associated with greater use of nonunion workplace dispute resolution procedures, but at a level still substantially below that of union procedures.

Evidence of broader impacts of employment arbitration in the workplace is much more limited. One of the major arguments in favor of labor arbitration and grievance procedures in the unionized workplace is that they provide a voice function for employees, reducing the use of the exit option of quitting and saving organizations on costly turnover (Freeman and Medoff 1984). If employment arbitration provides workers with a substantial voice mechanism in the workplace, akin to labor arbitration, then it might be expected to produce a corresponding reduction in voluntary turnover. However, in a study examining the impact of institutions, voice mechanisms, and human resource practices on quit rates; Batt, Colvin and Keefe (2002) found no evidence of a significant effect of employment arbitration on quit rates. Another possible impact of employment arbitration is on the reactions and attitudes of employees who are presented with mandatory arbitration agreements to be signed as a term and condition of employment. For example, in adopting an employment arbitration procedure, TRW decided to make arbitration non-binding for employees so as to avoid creating the impression that the company was engaging in a 'take-away' of employee rights, which would have 
contradicted its overall high commitment human resource strategy (Colvin 2004b). Empirical support for this concern is provided by a recent study showing that presentation of employment arbitration agreements lacking in due process protections has a negative effect on prospective employees in the selection process (Mahony, Klaas, McClendon and Varma 2005).

\section{Analysis}

Does the system of employment arbitration that is emerging in the nonunion workplace have the makings of an individual rights era version of the old labor arbitration and grievance procedure system of the collective bargaining-based industrial relations system? Were Gilmer and Circuit City the first steps in a new 'arbitration trilogy' of legal decisions setting the groundwork for a new system of workplace dispute resolution? To date the evidence suggests that the rise of employment arbitration is a significant new development in the workplace. Increasing numbers of workers are covered by these procedures and they do represent something different than the previous nonunion grievance procedures, in terms of both structure and employee usage. Yet the limitations of employment arbitration are also noteworthy. Although employment arbitration does appear to be associated with some enhancement of nonunion grievance procedures, either due to direct effects or perhaps synergies in the adoption process that lead to other enhancements in workplace dispute resolution procedures when arbitration is adopted (Colvin 2004b), it is also important to recognize that employment arbitration is primarily directed at replacing and shielding companies from litigation. Whether it is an effective replacement depends on the perspective one takes. The evidence suggests it is a simpler and faster procedure for resolving disputes. However, the evidence also suggests that arbitration outcomes are less favorable to employees than those from the court system. In addition, while employment arbitration appears to have advantages over nonunion grievance procedures that feature solely management decision-makers, it has limitations in usage and effectiveness for employees compared to grievance and arbitration procedures in unionized workplaces and less favorable outcomes for employees than litigation. More generally, employment arbitration suffers from the lack of employee voice in the development, design, and adoption of procedures, particularly in comparison to the jointly administered labor arbitration procedures of unionized workplaces (Budd and Colvin 2008). The picture at present is a mixed one in which employment arbitration may represent an enhancement of existing nonunion grievance procedures, but falls short of a strong, well-developed system of workplace dispute resolution serving the interests of both the employers and employees. 


\section{Conclusion: the pillars of a new system?}

The old collective bargaining-based industrial relations system was based on three pillars. Employment relations in the workplace were governed by detailed labor contracts regulating all aspects of employment decision-making in the workplace. These rules governing the workplace were negotiated based on the bargaining power of the parties, which derived from the ability of the labor to launch and the management to resist strikes. Finally, enforcement of labor contracts and resolution of rights disputes in the workplace occurred through jointly administered grievance procedures that culminated in binding, neutral labor arbitration.

The new individual rights-based employment relations system partly replicates these three pillars. First, employment relations in the workplace are governed by a new set of primarily statutebased individual employment rights. However, these rights only cover a limited set of employment decisions in the workplace, particularly those implicating issues of discrimination in employment, and leave most of the decisions to the unilateral discretion of management. Second, litigation provides employees with a new source of bargaining power in the workplace, akin to the strike power in traditional industrial relations. However, although the potential for sizable damage awards creates a substantial threat for management, the actual number of employment law disputes that reach trial and result in verdicts is relatively small, weakening the ability of any particular group of employees to utilize this weapon. Finally, the expansion of employment arbitration and other employment dispute resolution mechanisms, such as peer review and mediation, have established a new system of workplace dispute resolution. However, the incidence, structure, and due process protections of these procedures varies widely, creating much greater inequality in access to workplace dispute resolution than under the old labor arbitration system. The result is that the new individual rights-based employment relations system is one in which the three pillars only support a more limited set of equity protections and employee's voice in the governance of employment relations than the old collective bargaining-based system that they are supplanting.

Are these elements enough to conclude that there is an emerging individual employment rights system? Not in the sense in which we traditionally think of a national industrial relations system. It is a mistake to assume that the same factors, processes, and outcomes are necessarily important across a whole new employment relations 'system'. Rather we are seeing the development of an era in which law, institutions, and strategies are producing a range of different conflicts, interactions, and outcomes. The key is to understand the forces involved and what they are producing. The evidence does support a substantial role for individual rights laws and their enforcement mechanisms in governing employment 
relations, which suggests that the image of the American employment relations as an unconstrained labor market driven only by economic pressures and human resource strategies is an exaggeration. At the same time, it is a mistake to view these developments as representing the emergence of a new individual employment rights system, replacing but akin in some way to the earlier industrial relations system. Although individual employment rights laws have expanded substantially in the United States, they remain relatively narrow in their focus and do not appear to be leading to a broader set of worker rights applicable to all employment relations conflicts. Similarly, while employment litigation has emerged as a new source of countervailing power for employees and casts a significant shadow over management behavior in employment relations, employees vary widely in their ability to mobilize this new source of employee power. Finally, although there has been a major expansion of new ADR mechanisms in nonunion workplaces and some of these have an important role in governing employment relations, equally striking is the diversity in incidence, structure, and effectiveness of these mechanisms. Overall, the picture is not one of the emergence of a coherent, widespread new individual employment rights system, but rather of an individual rights era in which new employee rights and sources of power have arisen and have produced a divergence between different workers and workplaces in the ability to access and mobilize these rights and sources of power. 


\section{References}

Batt, R., Colvin, A.J.S., and Keefe, J. (2002), 'Employee Voice, Human Resource Practices, and Quit Rates: Evidence From the Telecommunications Industry,' Industrial and Labor Relations Review, 55, 4, 573-594.

Bennett-Alexander, D.D., and Hartman, L.P. (2004), Employment Law for Business (4th ed.), Chicago, IL: Richard D. Irwin, Inc.

Berenbeim, R. (1980), Nonunion Complaint Systems: A Corporate Appraisal, New York: The Conference Board.

Bingham, L.B. (1995), 'Is There a Bias in Arbitration of Non-Union Employment Disputes?' International Journal of Conflict Management, 6, 369-397.

Bingham, L.B. (1996), 'Emerging Due Process Concerns in Employment Arbitration: A Look at Actual Cases,' Labor Law Journal, 47, 2, 108-126.

Bingham, L.B. (1997), 'Employment Arbitration: The Repeat Player Effect,' Employee Rights and Employment Policy Journal, 1, 189-220.

Bingham, L.B. (1998), 'An Overview of Employment Arbitration in the United States: Law, Public Policy and Data,' New Zealand Journal of Industrial Relations, 23, 2, 5-19.

Bingham, L.B., and Mesch, D.J. (2000), 'Decision Making in Employment and Labor Arbitration,' Industrial Relations, 39, 4, 671-694.

Block, R.N., and Roberts, K. (2000), 'A Comparison of Labour Standards in the United States and Canada,' Relations Industrielles/Industrial Relations, 55, 2, 273-307.

Block, R.N., Roberts, K., and Clarke, R.O. (2003), Labor Standards in the United States and Canada, Kalamazoo, MI: W.E. Upjohn Institute for Employment Research.

Budd, J.W. (2004), Employment with a Human Face: Balancing Efficiency, Equity, and Voice, Ithaca, NY: Cornell University Press.

Budd, J.W., and Colvin, A.J.S. (2008), 'Improved Metrics for Workplace Dispute Resolution Procedures: Efficiency, Equity, and Voice,' Industrial Relations, 43, 3, 460-479.

Clermont, K.M., and Schwab, S.J. (2004), 'How Employment Discrimination Plaintiffs Fare in Federal Court,' Journal of Empirical Legal Studies, 1, 2, 429-458.

Colvin, A.J.S. (2001), 'The Relationship Between Employment Arbitration and Workplace Dispute Resolution Procedures,' Ohio State Journal on Dispute Resolution, 16, 3, 643-668.

Colvin, A.J.S. (2003a), 'Institutional Pressures, Human Resource Strategies, and the Rise of Nonunion Dispute Resolution Procedures,' Industrial and Labor Relations Review, 56, 3, 375-392. 
Colvin, A.J.S. (2003b), 'The Dual Transformation of Workplace Dispute Resolution,' Industrial Relations, $52,4,712-735$.

Colvin, A.J.S. (2004a), 'From Supreme Court to Shopfloor: Mandatory Arbitration and the Reconfiguration of Workplace Dispute Resolution,' Cornell Journal of Law and Public Policy, $13,3,581-597$.

Colvin, A.J.S. (2004b), 'Adoption and Use of Dispute Resolution Procedures in the Nonunion Workplace,' Advances in Industrial and Labor Relations, 13, 71-97.

Colvin, A.J.S. (2006), 'Flexibility and Fairness in Liberal Market Economies: The Comparative Impact of the Legal Environment and High Performance Work Systems,' British Journal of Industrial Relations, 44, 1, 73-97.

Colvin, A.J.S. (2008), 'Empirical Research on Employment Arbitration: Clarity Amidst the Sound and Fury?' Employee Rights and Employment Policy Journal, 11, 2, 405-447.

Colvin, A.J.S. (2011), 'An Empirical Study of Employment Arbitration: Case Outcomes and Processes,' Journal of Empirical Legal Studies, 8, 1, 1-23.

Delikat, M.M., and Kleiner, M. (2003), 'An Empirical Study of Dispute Resolution Mechanisms: Where do Plaintiffs Better Vindicate Their Rights?' Dispute Resolution Journal, 58, 4, 56-58.

Dertouzos, J.N., Holland, E., and Ebener, P. (1988), The Legal and Economic Consequences of Wrongful Termination, Santa Monica, CA: Rand Corporation.

Dunlop, J.T. (1958), Industrial Relations Systems, New York: Henry Holt and Company.

Eaton, A.E., and Keefe, J.H. (1999), Employment Dispute Resolution and Worker Rights in the Changing Workplace, Champaign, IL: Industrial Relations Research Association (IRRA).

Edelman, L.B. (1990), 'Legal Environments and Organizational Governance: The Expansion of Due Process in the American Workplace,' American Journal of Sociology, 95, 1401-1440.

Edelman, L.B., Uggen, C., and Erlanger, H.S. (1999), 'The Endogeneity of Legal Regulation: Grievance Procedures as Rational Myth,' American Journal of Sociology, 105, 2, 406-454.

Edwards, R. (1993), Rights at Work: Employment Relations in the Post-Union Era, Washington, DC: Brookings Institution.

Eisenberg, T., and Hill, E. (2003), 'Arbitration and Litigation of Employment Claims: An Empirical Comparison,' Dispute Resolution Journal, 58, 4, 44-55.

Eisenberg, T., and Schlanger, M. (2003), 'Reliability of the Administrative Office of the U.S. Courts Database: An Initial Empirical Analysis,' Notre Dame Law Review, 78, 1455-1496.

Estreicher, S. (2001), 'Saturns for Rickshaws: The Stakes in the Debate Over Predispute Employment Arbitration Agreements,' Ohio State Journal on Dispute Resolution, 16, 559-570. 
Ewing, D.W. (1989), Justice on the Job: Resolving Grievances in the Nonunion Workplace, Boston, MA: Harvard Business School Press.

Feuille, P., and Chachere, D.R. (1995), 'Looking Fair or Being Fair: Remedial Voice Procedures in Nonunion Workplaces,' Journal of Management, 21, 27-42.

Feuille, P., and Delaney, J.T. (1992), 'The Individual Pursuit of Organizational Justice: Grievance Procedures in Nonunion Workplaces,' Research in Personnel and Human Resources Management, 10, 187-232.

Freeman, R., and Medoff, J. (1984), What Do Unions Do? New York: Basic Books.

Friedman, S., Hurd, R.W., Oswald, R.A., and Seeber, R.L. (eds.) (1994), Restoring the Promise of American Labor Law, Ithaca, NY: ILR Press.

General Accounting Office (GAO) (1995), Employment Discrimination: Most Private-Sector Employers Use Alternative Dispute Resolution, Washington, DC: United States General Accounting Office (GAO/HEHS-95-150 Employment Discrimination).

Godard, J. (2002), 'Institutional Environments, Employer Practices, and States in Liberal Market Economies,' Industrial Relations, 41, 2, 249-286.

Hill, E. (2003), 'AAA Employment Arbitration: A Fair Forum at Low Cost,' Dispute Resolution Journal, 58, $2,8-17$.

Katz, H.C., Kochan, T.A., and Colvin, A.J.S. (2008), An Introduction to Collective Bargaining and Industrial Relations (4th ed.), New York: McGraw-Hill Irwin.

Lewin, D. (1987), 'Dispute Resolution in the Nonunion Firm: A Theoretical and Empirical Analysis,' Journal of Conflict Resolution, 31, 3, 465-502.

Lewin, D. (1990), 'Grievance Procedures in Nonunion Workplaces: An Empirical Analysis of Usage, Dynamics, and Outcomes,' Chicago-Kent Law Review, 66, 3, 823-844.

Lewin, D. (2008), 'Employee Voice and Mutual Gains,' Proceedings of the 60th Annual Meetings of the Labor and Employment Relations Association (LERA), 61-83.

Mahony, D.M., Klaas, B.S., McClendon, J.A., and Varma, A. (2005), 'The Effects of Employment Arbitration Systems on Applicants' Attraction to Organizations,' Human Resource Management, $44,4,449-470$.

McCabe, D.M. (1988), Corporate Nonunion Complaint Procedures and Systems, New York: Praeger.

Oppenheimer, D.B. (2003), 'Verdicts Matter: An Empirical Study of California Employment Discrimination and Wrongful Discharge Jury Verdicts Reveals Low Success Rates for Women and Minorities,' U.C. Davis Law Review, 37, 511-566. 
Piore, M.J., and Safford, S. (2006), 'Changing Regimes of Workplace Governance, Shifting Axes of Social Mobilization and the Challenge to Industrial Relations Theory,' Industrial Relations, 45, 3, 299325.

Schwartz, D. (2008), 'Mandatory Arbitration and Fairness,' Notre Dame Law Review, 84, 1247-1342.

Sherwyn, D., Estreicher, S., and Heise, M. (2005), 'Assessing the Case for Employment Arbitration: A New Direction for Empirical Research,' Stanford Law Review, 57, 1557-1591.

Slichter, S., Healy, J.J., and Livernash, E.R. (1960), The Impact of Collective Bargaining on Management, Washington, DC: The Brookings Institution.

Stone, K.V.W. (1996), 'Mandatory Arbitration of Individual Employment Rights: The Yellow Dog Contract of the 1990's,' Denver University Law Review, 73, 1017-1050.

Sutton, J.R., and Dobbin, F. (1996), 'The Two Faces of Governance: Responses to Legal Uncertainty in U.S. Firms, 1955 to 1985,' American Sociological Review, 61, 794-811.

Sutton, J.R., Dobbin, F., Meyer, J., and Scott, W.R. (1994), 'The Legalization of the Workplace,' American Journal of Sociology, 99, 944-971.

Westin, A.F., and Felieu, A.G. (1988), Resolving Employment Disputes Without Litigation, Washington, DC: Bureau of National Affairs.

Wheeler, H.N., Klaas, B.S., and Mahony, D.M. (2004), Workplace Justice Without Unions, Kalamazoo, MI: W.E. Upjohn Institute for Employment Research. 